Dikumpulkan : 28 Februari 2017

Direvisi : 27 Maret 2017

Diterima : 28 Maret 2017

\title{
Keunggulan Wisata Kuliner Tahu di Korea
}

\author{
SUPRIADIANTO \\ Diploma Bahasa Korea, Sekolah Vokasi, Universitas Gadjah Mada \\ cadiuzaa12@yahoo.co.id
}

\begin{abstract}
The article entitled "The Advantage of Tofu Culinary Tourism in Korea" is a qualitative descriptive research framework that analysed on the types of tofu in Korea based on its philosophical and tourism value. In Korea, the soy-based tofu is cooked and combined into some foods of high nutritional value, distinctive, unique, and modern. These foods are the main attraction in the world of Korean tourism that should be enjoyed. The data in this article were collected and analysed through literature study from various sources of information. The results of this study indicate that in principle tofu in Korea and Indonesia do not have significant differences, but in Korea, they can serve the tofu in the form of distinctive foods that characterizes their local wisdom.
\end{abstract}

Keywords:

Tofu, Food, Tourism, Korea 


\section{Pendahuluan}

Korea merupakan salah satu negara maju di wilayah Asia Timur. Letak geografisnya pun sangat strategis dengan jumlah pegunungan terbanyak di dunia antara $33^{\circ}-44^{\circ}$ lintang Utara, dan $124^{\circ}-132^{\circ}$ lintang Bujur Timur, termasuk Korea Utara1. Letak geografis yang strategis dan unik ini menjadikan Korea sebagai negara negara penghubung di dunia internasional.

Abad ke-20 ini merupakan abad kejayaan Korea. Kejayaannya secara global didukung oleh berbagai faktor khususnya pariwisata. Kejayaan ini merupakan momentum yang sangat dimanfaatkan oleh Korea untuk memperkenalkan beragam keunggulan, keunikan, bahkan keistimewaannya kepada seluruh dunia, khususnya Indonesia. Bila berbicara masalah pariwisata Korea, maka tidak akan lepas dari ciri khas dan keunggulan tourisme special identities-nya seperti fashion, K-Pop, entertainment, dan kuliner.

Keempat produk unggulan Korea tersebut sudah sekian lama menjadi konsumsi kegiatan tourism masyarakat Indonesia dengan segenap ragam atraksinya, baik di Indonesia maupun di Korea. Indonesia merupakan pasar pariwisata yang sangat strategis dan produktif bagi Korea. Terkait hal tersebut Papatheodorou (2006, p.187) menyatakan "A relevant market normally has a product and a geographic dimension. It contains all those substitute products and regions which provide a significant competitive constraint on the products and regions of interest". Artinya, bahwa pasar yang relevan bagi suatu negara sebagai penyedia objek wisata (meliputi semua segmentasi produk wisata) dalam sebuah bidang pariwisata merupakan wilayah yang memilik dimensi produk dan dimensi geografis, di mana letak nilai unggul dan nilai istimewanya dimiliki oleh negara penyedia objek wisata tersebut.

Merujuk pada pernyataan Papatheodorou tersebut, Korea memiliki kriteria yang sangat sesuai untuk menjadi objek tujuan wisata masayarakat Indonesia. Misalnya, secara geografis Korea sangat strategis terhadap Indonesia dengan karakteristik iklim yang berbeda (meskipun dalam sektor demografis memiliki kemiripan). Perbedaan tersebut tentunya akan memberi daya tarik tersendiri bagi masyarakat Indonesia untuk mengunjungi Korea. Selain itu, dalam wisata kuliner bahan-bahan baku masakan Korea memiliki banyak kesamaan dengan bahan-bahan makanan khas Indonesia, misalnya daging sapi, sayur mayur, rempah-rempah, dan Tahu. Karakteristik masakan Korea justru memiliki nilai tambah dan keunikan tersendiri dibandingkan dengan masakan-masakan Indonesia. Masakan Korea yang berbahan dasar sama dengan masakan Indonesia mampu disajikan dengan variasi yang lebih beraneka ragam dan modern, bahkan dengan kandungan gizi yang lebih tinggi, akan mampu menjadi daya tarik yang sangat tinggi bagi masyarakat Indonesia.

Penilitian ini akan fokus pada potensi wisata masakan kuliner Korea yang berbahan Tahu. Fokus ini diambil oleh penulis karena Tahu merupakan bahan dasar makanan sehari-hari di Indonesia dalam beragam jenis variannya, tetapi di lain sisi Tahu juga merupakan bahan makanan khas Korea dalam berbagai produk makanan yang memiliki nilai modern, nilai unik, dan nilai gizi yang lebih tinggi. Dengan demikian, perbedaan jenisjenis makanan antara Indonesia dan Korea ini akan menjadi nilai lebih interest of culinary tour yang tersendiri meskipun berada dalam dimensi yang sama. 
Jenis-jenis Tahu di Indonesia dan Korea pada dasarnya memiliki banyak kesamaan. Misalnya, di Indonesia terdapat Tahu putih, Tahu kuning atau Tahu Kediri karena pusat produksinya berada di wilayah Kediri Jawa Timur, Tahu sutera, Tahu pong, Tahu susu, Tahu air, dan Tahu kulit. Adapun jenis-jenis Tahu di Korea juga beragam seperti Ilbandubu, Sundubu, Yeondubu, Yubu, dan Biji. Semua jenis Tahu tersebut di kedua negara tentunya memiliki perbedaan dan persamaan. Secara detail akan dibahas di dalam bagian temuan dan pembahasan.

Berdasarkan pra observasi yang telah dilakukan oleh penulis tampak perbedaan yang sangat besar antara jenisjenis makanan yang berbahan Tahu di Korea dan di Indonesia. Kombinasi dengan bahan lain yang disajikan bersama Tahu dalam masakan Korea lebih tampil modern, variatif, higienis, kreatif, dan unik. Informasi komprehensif diperlukan untuk mengetahui secara detail keunggulan dan keunikan masakan-masakan Korea yang berbahan dasar Tahu, yang tentunya layak menjadi daya tarik tersendiri bagi masyarakat Indonesia untuk melakukan wisata kuliner ke Korea.

Adapun pokok-pokok permasalahan yang menjadi fokus pembahasan dalam artikel ini meliputi (1) Apa saja jenis Tahu yang ada di Indonesia dan Korea serta bagaimana perbedaan diantaranya, (2) Makanan apa saja yang berbahan Tahu di Korea, dan (3) Bagaimana kekuatan pasar (market power) dan persaingannya (competition issues) makanan berbahan Tahu di Korea dalam dunia pariwisata di Indonesia dan Korea.

\section{Metode}

Kerangka penelitian ini adalah deskriptif kualitatif. Peneliti menelaah dan melakukan observasi baik dalam studi pustaka maupun media informasi yang lain, yang memberikan banyak inspirasi tentang karakteristik masing-masing variasi makanan berbahan dasar Tahu baik di Indonesia maupun di Korea. Koleksi data berupa data primer yakni jenis-jenis Tahu di Indonesia dan Korea, semua jenis makanan berbahan Tahu di kedua negara tersebut, nilai lebih dan potensi culinary tour interest masakan berbahan Tahu di Korea bagi masyarakat di Indonesia. Analisis data dilakukan dengan teknik komparasi komposisi, variasi, nilai gizi, dan nilai tambah serta keunikan makanan Korea berbahan Tahu terhadap makanan berbahan Tahu di Indonesia. Kemudian nilai kompetisi (rivalry) makanan-makanan di Korea tersebut dalam perindustrian wisata di Korea, di Indonesia, maupupun di dunia.

\section{Hasil dan Pembahasan Jenis Tahu di Korea}

Sebagaimana di Indonesia, Tahu di Korea berbahan dasar kedelai dan jenisnya pun sangat beragam sesuai dengan masing-masing fungsinya ketika dikombinasikan dengan bahan lain untuk disajikan dalam sebuah jenis makanan. Secara filosofis, Tahu memiliki peranan yang besar di Korea. Sesuai dengan warnanya yang putih masyarakat Korea meyakini bahwa Tahu merupakan simbol kesucian, sehingga setiap masyarakan Korea baru keluar dari penjara, maka akan selalu disajikan Tahu untuk dimakannya. Hal tersebut melambangkan bahwa orang tersebut telah kembali suci. Selain itu, bahan Tahu yaitu kedelai (soy bean) menyiratkan bahwa Tahu yang sudah putih dan lembut tidak akan kembali berubah wujud menjadi kedelai yang masih keras dan berbutiran kasar. Filosofi ini masih 
berkembang dan diyakini oleh penduduk Korea sampai saat ini.

Tahu diproduksi menjadi beberapa jenis di Korea. Setiap jenis memiliki karakteristik tersendiri, dan fungsinya pun berbeda-beda sebagai bahan kombinasi sebuah sajian makanan. Adapun jenis-jenis Tahu di Korea adalah sebagai berikut:

\section{a. Ilbandubu (일반두부)}

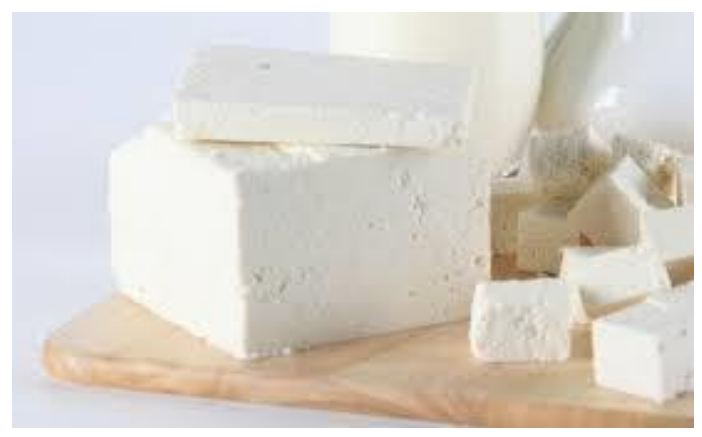

Gambar 1. Ilbandubu (일반두부)

Sumber: www.blog.daum.net/ilbandubu

Ilbandubu (일반두부) adalah jenis Tahu Korea yang sering di gunakan dalam masakan Jjigae (찌개), Buchim (부침), Twigim (튀김) dan Jorim (조림). Tahu ini sama seperti Tahu pada umumnya. Teksturnya tidak selembut Sundubu (순두부), tidak terlalu keras dan bisa langsung dimakan bersama Kimchi (김치).
Gambar 2. Sundubu (순두부)

Sumber: www.megamart.com/sundubu

Sundubu (순두부) adalah jenis Tahu Korea yang paling lembut. Sundubu (순두부) teksturnya lebih lembut dibandingkan Tofu. Tahu jenis ini sering digunakan pada masakan Jjigae maka dari itu di Korea terkenal dengan masakan Sundubu Jjigae (순두부찌개).

c. Yeondubu (연두부)

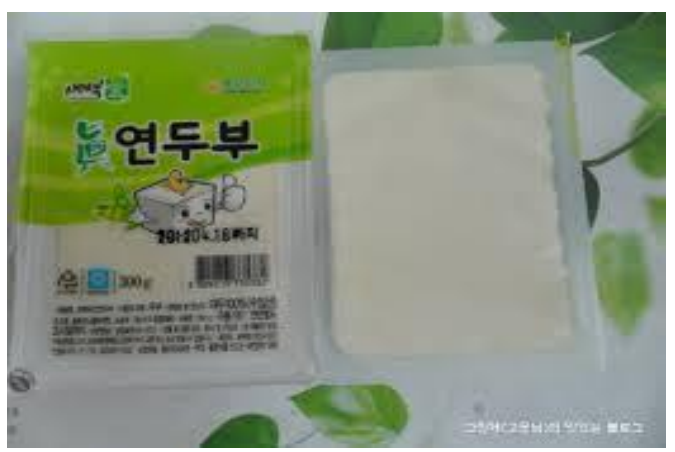

Gambar 3. Yeondubu (연두부)

Sumber: www.blog.daum.net/yeondubu

Yeondubu (연두부) adalah jenis Tahu Korea yang menyerupai puding. Tahu ini saat pembuatannya air tidak dikeluarkan. Tekstur dari Tahu ini sama seperti Sundubu (lembut). Jenis Tahu ini biasanya digunakan dalam masakan seperti puding, salad, dan lain-lain.

b. Sundubu (순두부)

d. Yubu (유부) 
Gambar 4. Yubu (유부)

Sumber: www.blog.daum.net/yubu

Yubu (유부) adalah jenis Tahu Korea yang digoreng dan biasanya digunakan di masakan Jepang seperti Udon atau Yubuchobab (유부초밥) nasi berbumbu yang dimasukkan dalam Yubu). Jenisnya sama di Indonesia seperti Tahu Pong atau Tahu Kulit.

\section{e. $\operatorname{Biji}(H / T /)$}

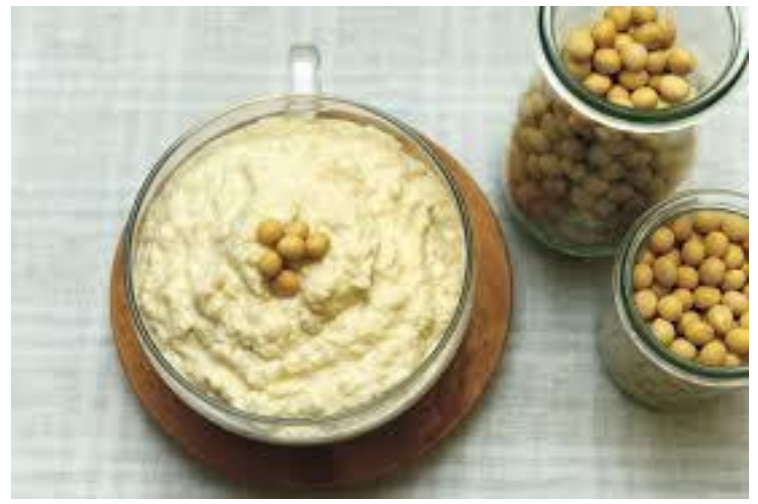

Gambar 5. Biji (비지)

Sumber : www.munhwa.com/biji

Biji ( $(H / T /)$ adalah jenis Tahu Korea yang biji kedelainya digiling, menyerupai bubur kedelai dan ampas kedelainya tidak dibuang. Contoh masakan Korea yang menggunakan Tahu jenis ini adalah Biji Jjigae (비지끼개).

\section{Jenis Tahu di Indonesia}

Tahu di Indonesia sama halnya dengan di Korea, yaitu berbahan dasar kedelai. Secara umum tekstur Tahu di Indonesia juga sama yaitu halus dan berwarna putih. Namun demikian, seiring dengan kreasi masyarakat dan aneka kebutuhan konsumsinya Tahu memiliki jenis yang bermacam-macam pula di Indonesia, antara lain sebagai berikut:

\section{a. Tahu Putih}

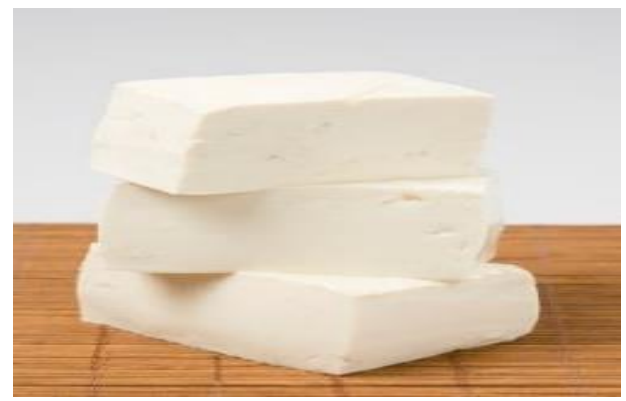

Gambar 6. Tahu Putih

Sumber: www.aninditanst.wordpress.com/Tahuputih

Tahu jenis ini teksturnya padat dengan pori-pori agak besar dan di pasaran dapat dijumpai dalam beragam bentuk dan ukuran. Tahu Putih cocok diolah menjadi lauk, hidangan berkuah (sup), aneka tumis, adonan isian, dan digoreng. Tahu Putih mudah hancur. Kualitas Tahu Putih hanya bisa bertahan selama dua hari, lebih dari itu akan terjadi perubahan aroma dan tekstur. Proses pengukusan dan penyimpanan dalam almari pendingin hanya mampu menambah usia konsumsi maksimal satu hari.

\section{b. Tahu Kuning}

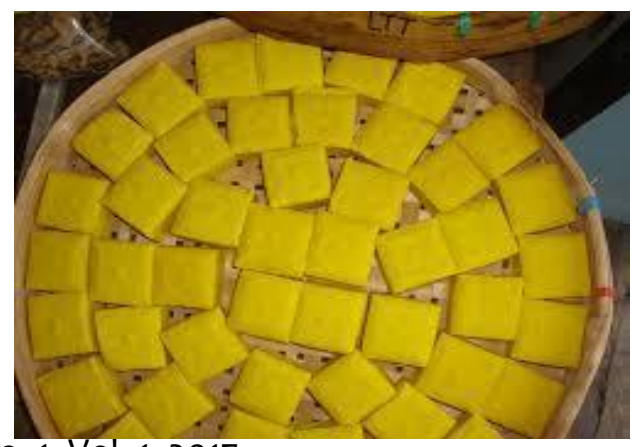




\section{Gambar 7. Tahu Kuning}

Sumber: www.jawawetan.wordpress.com/TahuKuning

Tahu ini dikenal juga dengan nama Tahu Kediri, karena pusat pembuatan Tahu ini banyak dijumpai di Kediri. Tekstur Tahu kuning sangat padat, kenyal, berpori halus, dan lembut. Bentuknya kotak segi empat dan agak pipih. Warna kuning pada Tahu menggunakan pewarna alami dari kunyit. Bentuknya yang tidak mudah hancur memudahkan dalam mengolah. Tahu Kuning bisa dimasak dalam bentuk tumisan, sup atau digoreng.

\section{c. Tahu Sutera (Tofu)}

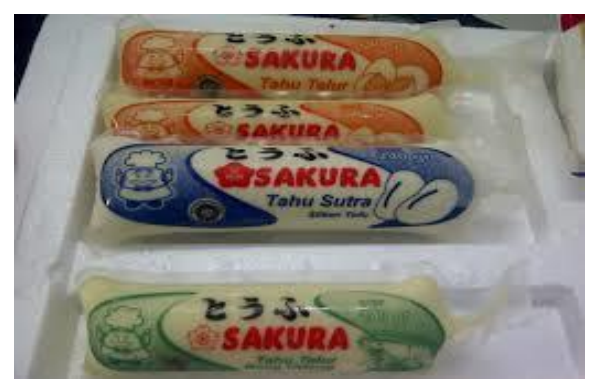

Gambar 8. Tahu Sutra

Sumber: www.fjb.kaskus.co.id/Tahu-sutera

Jenis makanan ini disebut Tahu sutera karena teksturnya sangat halus. Pada umumnya tofu berwarna putih. Tofu yang ditambah dengan telur dikenal dengan nama egg tofu, warnanya lebih kuning. Sedangkan, tofu dengan tambahan udang dinamakan shrimp tofu. Tofu lebih mudah dipilih karena dalam kemasannya telah tercantum tanggal kadaluarsa. Tekstur tofu yang sangat lembut, dan rapuh membutuhkan cara khusus saat mengolahnya.

d. Tahu Pong

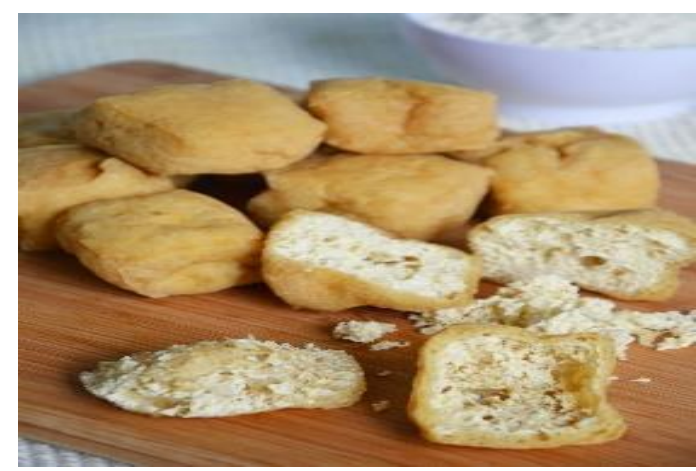

Gambar 9. Tahu Pong

Sumber: www.diahdidi.com/Tahu-pong

Tekstur Tahu Pong padat dengan pori-pori besar. Ciri khasnya ketika digoreng kering, maka bagian dalamnya akan terdapat rongga dan kulitnya akan kecokelatan dan renyah. Tahu Pong lebih umum disajikan untuk camilan dan campuran masakan berkuah, seperti pada makanan Bakso, Tahu Gejrot, dan lain.-lain.

e. Tahu Susu

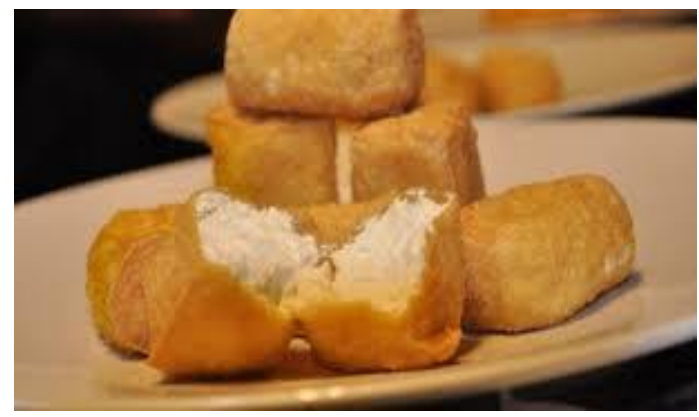

Gambar 10. Tahu Susu

Sumber: www.sebandung.com/Tahu-susu

Tahu susu diperoleh dari proses curdling (menggumpalkan) susu menggunakan lemon juice atau cuka, lalu menghilangkan bagian cairnya. Bagian susu yang telah mengumpal tersebut kemudian dipadatkan hingga terbentuk batangan Tahu yang padat. Tampilan Tahu susu mirip dengan Tahu air, tetapi lebih padat dan gurih. Pembuatan Tahu susu adalah salah satu upaya memanfaatkan 
susu yang kualitasnya rendah. Tahu susu cocok untuk olahan panggang seperti steak, digoreng, untuk campuran isi pai dan topping pizza.

\section{f. Tahu Air}

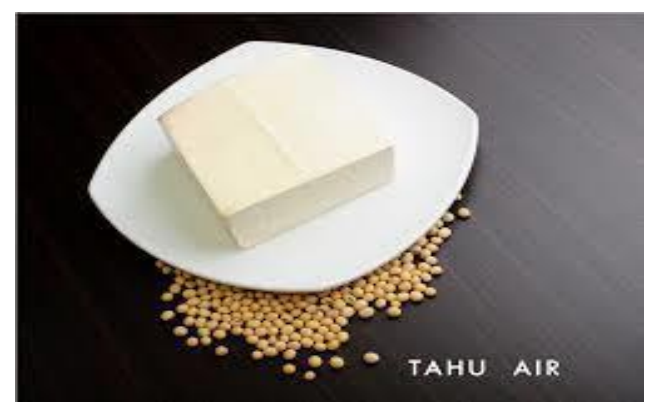

Gambar 11. Tahu Air

Sumber: www.Tahuyunyi.com/Tahu-air

Warnanya putih seperti Tahu putih, tetapi teksturnya lebih lembut dan lunak karena terbuat dari gumpalan susu kedelai yang dipadatkan. Tahu air cocok diolah untuk sapo, mapo dan beragam sajian berbumbu sechuan. Rasa Tahu putih lebih gurih dan lembut.

\section{g. Tahu Kulit}

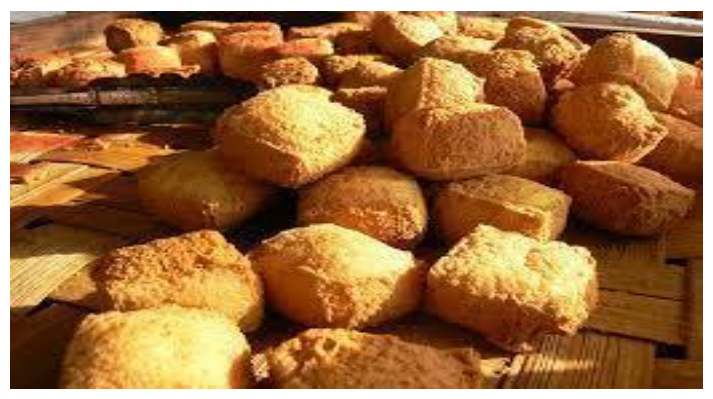

Gambar 12. Tahu Kulit

Sumber: www.agroyasa.com/Tahu-kulit

Jenis Tahu kulit paling populer adalah Tahu Sumedang. Kulitnya berwarna kecokelatan dengan rongga bagian dalam yang akan tampak jika Tahu digoreng. Tahu Sumedang termasuk Tahu siap makan, jadi tidak perlu mengolahnya lagi. Tahu ini cukup digoreng, lalu dimakan bersama saus atau cabe hijau kecil.

\section{Makanan Berbahan Tahu di Korea}

a. Gochujeon (고추전)

$$
\text { Gochujeon (고추전) adalah }
$$

masakan Korea yang terbuat dari Tahu dan cabe hijau (besar). Hidangan ini termasuk dalam sajian Appetizer (hidangan pembuka) dan cara memasak hidangan ini tidak menggunakan banyak minyak. Gochujeon (고추전) terbuat dari cabe hijau maka dari itu dari segi rasa masakan ini tidak pedas. Jeon biasanya di hidangkan dalam suatu pertemuan, pesta, dan hari libur khusus.

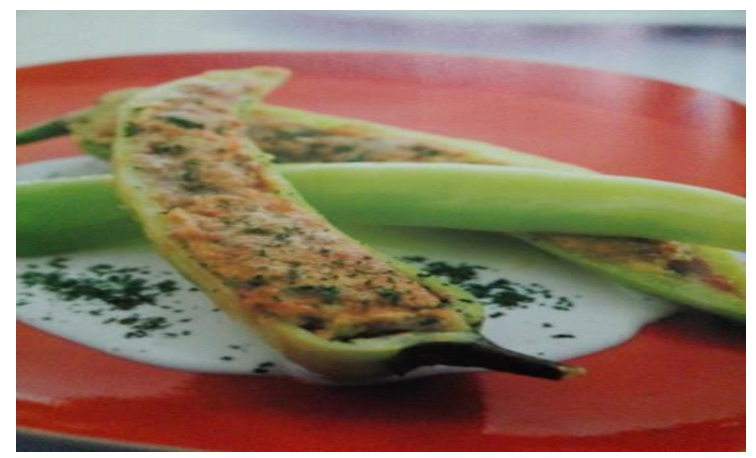

Gambar 13. Gochujeon (고추전)

Sumber : Buku resep “Korean Kitchen” hal.18

Bahan-bahan yang digunakan dalam pembuatan Gochujeon (고추전) terdiri dari: cabe hijau (besar) 4 buah, Daging Sapi (giling) 225 gram, Tahu Putih 115 gram, Tepung Terigu 1 cup, Telur 2 butir, dan Minyak Sayur secukupnya. Adapun bumbu yang digunakan terdiri dari Daun Bawang yang iris halus 2 sendok makan, Bawang Putih yang dicincang halus sejumlah $1 / 2$ sendok makan, Minyak Wijen 1 sendok teh, Biji Wijen 1 sendok makan, dan Garam serta Merica secukupnya. Selanjutnya, bumbu perlu ditambahkan 
saus pelengkap yang terdiri dari Kecap Asin 2 sendok makan, Air Jeruk Lemon 2 sendok makan, Mustard 1 sendok makan, Gula 1 sendok teh, Daun Bawang yang diiris halus 1 sendok teh, dan garam serta merica secukupnya.

\section{b. Dubu Kimchi (두부김치)}

Dubu Kimchi (두부김치) adalah masakan Korea yang terbuat dari Tahu dan Kimchi. Dubu Kimchi (두부김ㅊ) termasuk hidangan Appetizer atau sering disebut Anjoo (안주) hidangan yang disajikan sebagai pendamping ketika minum alkohol/ Soju). Saat dihidangkan Kimchi (김ㅊ/) berada di tengah-tengah Tahu. Cara memakannya Kimchi diletakkan di atas Tahu kemudian langsung dilanjutkan dengan minum Soju (소주l alkohol Korea).

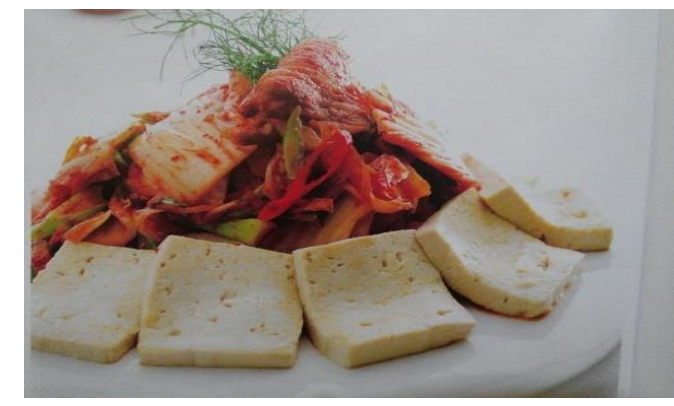

Gambar 14. Dubu Kimchi (두부김치)

Sumber: Buku resep "Korean Kitchen” hal.94

Pada masakan Dubu Kimchi (두부김치) bagi para Vegetarian daging sapi maupun daging babi bisa dihilangkan.

Dalam proses pembuatan Dubu Kimchi (두부김치) ini menggunakan bahanbahan yang terdiri dari: Tahu Putih yang dipotong kotak lalu bagi menjadi dua p pack sebanyak 500gram, Daging Babi (bisa di gant dengan daging sapi) yang iris tpis- tipis sebanyak 350gram, Kimchi 450 gram, Mentega 1 sendok makan, Bawang Bombay diiris tipis $1 / 2$ irisan, Cabe Merah dipotong miring 1 buah, Daun Bawang 4 sendok makan, Minyak sayur secukupnya. Adapun bumbu yang digunakan terdiri dari Kecap Asin 1 sendok makan, Gochugaru 1 sendok makan, Gochujang 1 sendok makan, Gula 1 sendok makan, Bawang Putih 1 sendok teh, Jahe $1 / 2$ sendok teh, dan Minyak Wijen $1 / 2$ sendok makan.

c. Dwenjang Jjigae (된장찌개)

Dwenjang Jjigae (된장찌개) adalah masakan berkuah tradisional di Korea. Rasa pasta kedelai sangat menyatu dengan sayuran hangat seperti lobak Korea dan lobak jepang. Rebusan Dwenjang Jjigae (된장찌개) akan sempurna dengan tambahan Tahu. Dwenjang Jjigae (된장찌개) sangat cocok dihidangkan untuk melengkapi sajian Bulgogi (불고기), Galbi (갈비), dan ikan bakar. Kualitas Dwenjang Jjigae (된장째/개) tergantung pada pasta kedelai dan kekayaan kaldu dasar. Saat dihidangkan, Dwenjang Jjigae (된장찌개) biasanya menggunakan dolsot (돌솥/ mangkuk batu panas) supaya Dwenjang Jjigae (된장찌개) selalu hangat saat dimakan. 
Gambar 15. Dwenjang Jjigae (된장찌개)

Sumber : Buku resep "Korean Kitchen" hal.142

Bahan-bahan yang digunakan
dalam pembuatan Dwenjang Jjigae (된장찌개) ini terdiri dari: Mentega 1 sendok makan, Bawang Putih yang dicincang halus 1 sendok teh, Daging sapi (tanpa lemak) diiris tipis 110 gram, Bawang Bombay diiris tipis $1 / 2$ potong, Dwenjang 6 sendok makan, Tahu Putih dipotong dengan bentuk dadu 450 gram, Lobak jepang dipotong bentuk dadu 1 buah, Cabe Merah dipotong miring 2 buah, Cabe Hijau dipotong miring 2 buah, dan Daun Bawang dipotong miring 2 batang.

\section{d. Kimchi Jjigae (김치찌개)}

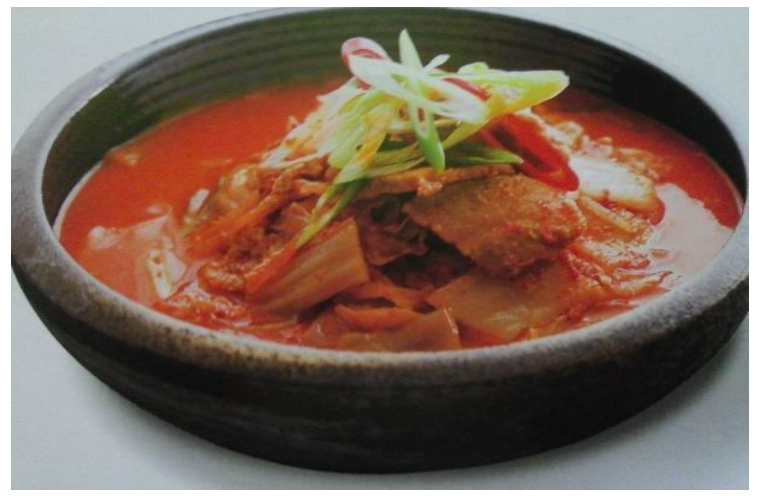

Gambar 16. Kimchi Jjigae (김치찌개)

Sumber : Buku resep “Korea Kichen” hal. 143

Adalah masakan Korea kategori sup (kental). Dari segi rasa sedikit pedas dan asam. Kimchi Jjigae (김치찌/개) biasanya dinikmati saat musim dingin. Kimchi Jjigae (김치찌/개) di Korea bisa dinikmati kapan saja dan dimana saja. Banyak variasi dalam masakan ini tergantung selera masing- masing. Masakan ini dapat ditambahkan kentang, jamur, dan lain sebagainya. Saat dihidangkan, Kimchi Jjigae (김치째/개) biasanya menggunakan Dolsot (돌솥) mangkuk batu panas) supaya Kimchi Jjigae (김치찌개) selalu hangat saat dimakan.

Bahan-bahan yang digunakan untuk membuat Kimchi Jjigae (김치찌개) terdiri dari: Mentega 2 sendok makan, Bawang Putih cincang halus 1 sendok teh, Bawang Bombay diiris panjang $1 / 2$ potong, daging babi (bisa diganti dengan daging sapi) yang dipotong-potong kecil 450 gram, Kimchi 900 gram, Tahu Putih 1 pack (500 gram), Gula $1 / 2$ sendok makan, Air Kimchi $1 / 2$ cup, Air $1 / 2$ cup, dan Daun Bawang dipotong miring 1 batang.

\section{e. Sundubu Jjigae (순두부찌개)}

Sundubu Jjigae (순두부찌/개) adalah sup Tahu (lembut) pedas khas Korea. Kombinasi antara aroma daging, seafood, sayuran, dan bumbu pedas dengan Sundubu (Tahu Korea yang sangat lembut). Sundubu dapat menjadi hidangan lengkap ketika dihidangkan bersama semangkuk nasi hangat. Selain itu, Sundubu Jjigae (순두부찌개) dapat divariasi dengan berbagai macam daging atau dengan seafood saja. Saat dihidangkan, Sundubu Jjigae (순두부찌개) biasanya menggunakan Dolsot (돌솥/ mangkuk batu panas) supaya Sundubu Jjigae (순두부찌개) selalu hangat saat dimakan. 
Gambar 17. Sundubu Jjigae (순두부찌개)

Sumber : Buku resep “Korean Kitchen” hal. 144

Bahan-bahan yang digunakan untuk membuat Sundubu Jjigae (순두부찌개) terdiri dari: daging babi (bisa diganti dengan daging sapi) yang diiris tipis 115 gram, Udang medium 115 gram, Kerang 60 gram, Kerang Tiram 60 gram, Kerang kecil 80 gram, Tahu Sutera (Tofu) 625 gram, Jamur Shitake 6 buah, Daun Bawang 2 batang, Minyak Zaitun secukupnya dan air 1/3 cup. Selanjutnya adapun bumbu yang digunakan terdiri dari: Gochugaru 1 sendok makan, Kecap Asin 1 sendok makan, Kecap Ikan 1 sendok makan, Daun Bawang diiris halus 2 sendok makan, Bawang putih yang dicincang halus 1 sendok teh, Biji Wijen 1 sendok teh, Minyak Wijen 1 sendok teh, dan Garam serta merica secukupnya.

f. Dwejigogi Dubu Gochujang Jjigae (대지고기두부고추장찌개)

Dwejigogi Dubu Gochujang Jjigae (대지고기두부고추장찌개) adalah sup (kental) Tahu dan daging babi. Hidangan ini tidak menggunakan sayuran saat memasak, hanya menggunakan daun bawang. Daging sapi dapat digunakan sebagai ganti daging babi saat membuat masakan ini.

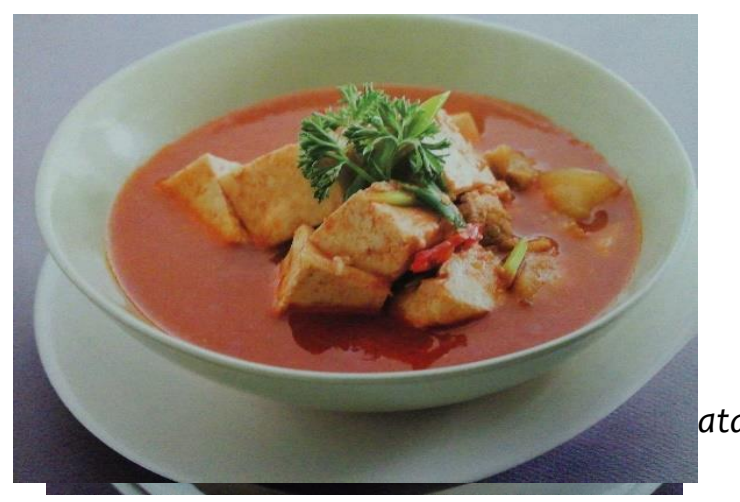

Gambar 18. Dwejigogi Dubu Gochujang Jjigae

(돼지고기두부고추장찌개)

Sumber : Buku resep “Korean Kitchen” hal. 146

Bahan- bahan untuk membuat Dwejigogi Dubu Gochujang Jjigae (돼지고기두부고추장찌개) terdiri dari: Daging Babi, potong ukuran $1 \mathrm{~cm}$ (bisa diganti daging sapi) 450 gram, Bawang Bombay 1 buah, Tahu Putih 1 pack (500 gram), Daun Bawang Besar dipotong miring $1 / 2$ batang, Daun bawang dipotong miring 2 batang, dan air secukupnya.

\section{g. Daehap Gui (대합구이)}

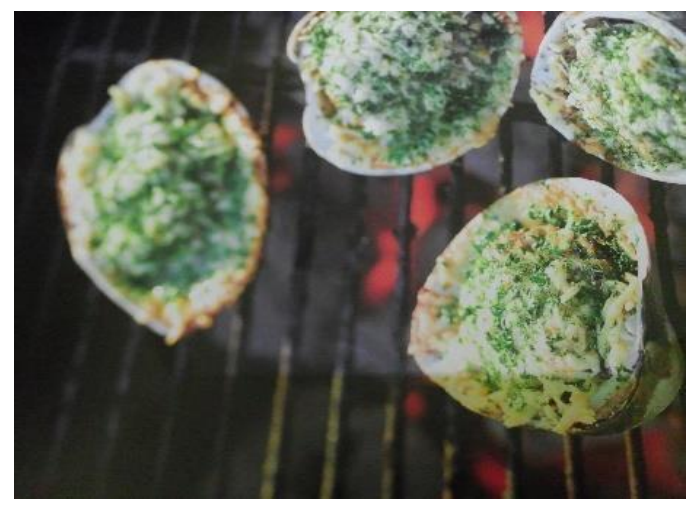

Gambar 19. Daehap Gui (대합구이)

Sumber : Buku resep “Korean Kitchen” hal. 38

Daehap Gui (대합구이) adalah cangkang kerang yang diisi dengan daging, Tahu, dan bahan lain lalu dipanggang. Masakan ini menggunakan kerang yang bercangkang besar. Daehap Gui (대합구이) adalah masakan tradisional Korea. Masakan ini termasuk dalam sajian Appetizer (makanan pembuka). 
Bahan- bahan untuk membuat Daehap Gui (대합구O) terdiri dari: Kerang (dengan cangkang besar) 12 gram, Tahu putih 60 gram, Daging Sapi (giling) 60 gram, Jamur Shitake yang diiris halus 2 buah, Keju Permesan secukupnya, Daun Parsley 4 sendok makan, dan Minyak Zaitun secukupnya. Adapun bumbu-bumbu yang digunakan terdiri dari: Kuning telur 1 butir, Gula 1 1/2 sendok teh, Bawang Putih 1 sendok teh, Daun Bawang 2 sendok makan, Minyak Wijen 1 sendok teh, Biji Wijen 1 sendok makan, dan garam serta merica secukupnya.

h. Pyeonsu (편수)

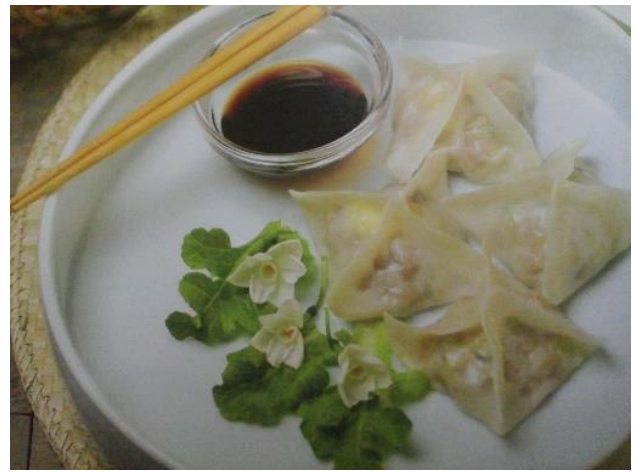

Gambar 19. Pyeonsu (편수)

Sumber : Buku resep "Modern Korean Cooking” hal. 28

Pyeonsu (편수) adalah masakan Korea semacam mandu. Nama "Pyeonsu" berasal dari Cina yang artinya "sebuah fragmen kecil di atas air”. Pyeonsu (편수) adalah makanan saat musim panas. Pyeonsu (편수) biasanya disajikan dingin, atau disajikan dengan sup kecap asin dingin. Pyeonsu (편수) termasuk dalam sajian Appetizer (makanan pembuka).

Bahan- bahan untuk membuat Pyeonsu (편수) terdiri dari: Kulit Mandu yang berbentuk kotak 1 pack, Daging Sapi (giling)/ Daging Babi 150 gram, Tahu Putih $1 / 2$ pack (250 gram), Jamur Shitake yang rendam dalam air hangat selama 30 menit lalu iris halus 2 buah, Lobak jepang yang diparut lalu taburi garam 1 buah, Telur yang dimasak dadar lalu potong kotak-kotak 1 butir, Pine Nuts 2 sendok makan, dan Putir Telur 1 butir. Selanjutnya adpun bumbubumbu yang digunakan terdiri dari: Kecap Asin 1 sendok teh, Garam 1/4 sendok teh, Bawang Putih yang dicincang halus 1 sendok teh, Daun Bawang yang diiris halus 1 sendok makan, Biji Wijen disangrai 1 sendok teh, Minyak Wijen 1 sendok makan, Black Pepper 1/8 sendok teh, dan Jahe 1 sendok teh, kemudian setelah itu ditambahkan dengan saus pelengkap yang terdiri dari: Kecap Asin 1 sendok makan, Gula $1 / 2$ sendok makan, dan Vinegar 1/2 sendok makan.

\section{i. Dubu Gui (두부구O)}

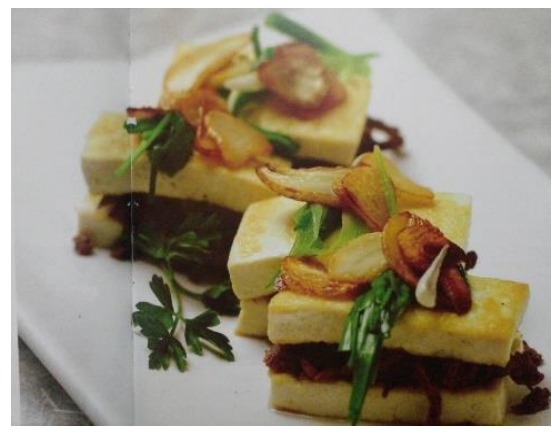

Gambar 20. Dubu Gui (두부구이)

Sumber : Buku resep "Modern Korean Cooking” hal. 36

Dubu Gui (두부구이) adalah masakan Korea yang terbuat dari Tahu dan daging yang dipanggang. Masakan ini bentuknya seperti sandwich karena cara menyajikannya dengan cara daging berada diantara dua Tahu yang sudah dipanggang. Masakan ini sangat sederhana dan mudah untuk membuatnya. Dubu Gui (두부구이) 
termasuk dalam sajian Appetizer (makanan pembuka).

Bahan- bahan untuk membuat Dubu Gui (두부구O/) terdiri dari: Tahu putih yang dipotong ukuran persegi panjang dengan tebal $1 \mathrm{~cm}$ sebanyak 1 pack (500 gram), Daging Sapi has dalam (thenderloin) yang dipotong tipis dan panjang seperti Tahu 150 gram, Bawang Putih diiris tipis 2 siung, Garam 1 sendok teh, dan Minyak sayur secukupnya.

Selanjutnya, bumbu yang digunakan untuk melumuri daging menggunakan bumbu yang terdiri dari: Kecap Asin 1 sendok makan, Gula Coklat 1 sendok makan, Minyak Wijen 1 sendok teh, Bawang Putih yang dicincang halus $1 / 2$ sendok teh, Daun Bawang yang diiris halus $1 / 2$ sendok teh, dan Black Pepper secukupnya.

j. Saengdubu Yachae Muchim (생두부야채무참)

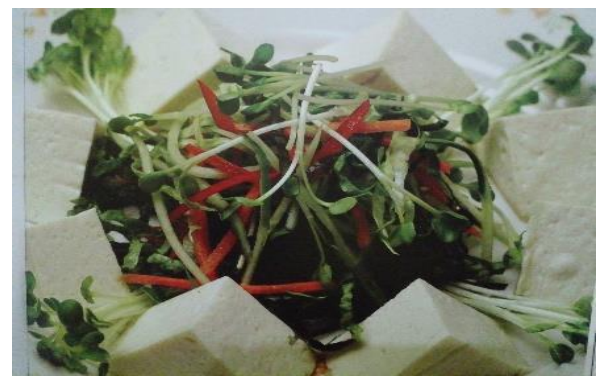

Gambar 21. Saengdubu Yachae Muchim (생두부야채무침)
Sumber : Buku resep "Modern Korean Cooking" hal.62

Saengdubu Yachae Muchim (생두부야채무첨) adalah masakan yang terbuat dari Tahu yang direbus dan sayuran mentah yang ditata lalu diberi saus dari kecap asin. Saengdubu Yachae Muchim (생두부야채무침) termasuk dalam sajian Salad. Hidangan ini sangat cocok bagi para vegetarian atau yang sedang menjalani proses diet.

Bahan- bahan untuk membuat Saengdubu Yachae Muchim (생두부야채무첨) terdiri dari: Tahu Putih atau Tofu $1 / 2$ pack, Lettuce dipotong kecilkecil berbentuk korek api 1 cup, Timun dipotong kecil memanjang $1 / 2$ buah, wortel dipotong kecil memanjang $1 / 2$ buah, Radish sprout $1 / 2$ pack, dan Paprika merah yang dipotong kecil memanjang $1 / 4$ buah.

Selanjutnya, untuk saus yang digunakan dibuat dengan bahan-bahan yang terdiri dari: Kecap asin 2 sendok makan, Daun Bawang diiris halus 1 batang, Bawang Putih yang dicincang halus 1 siung, Biji wijen yang disangrai 1 sendok teh, Gula 1 sendok makan, Vinegar 1 sendok makan, dan Minyak wijen 1 sendok teh.

\section{Market Power dan Competition Isuue Makanan Berbahan Tahu di Korea}

Sebagaimana telah dijelaskan sebelumnya, bahwa Korea memiliki dimensi pasar yang mengungguli produk makanan berbahan Tahu yang ada di Indonesia. Keunggulan produk tersebut juga didukung oleh dimensi geografis yang memberikan kekuatan pada pasar wisata di Korea. Letak geografis tersebut memiliki kekhasan tersendiri di Asia Timur yang sangat mendukung untuk menjadi sebuah 
wilayah destinasi wisata yang maju di dunia, khususnya di Asia.

Ciri khas masakan berbahan Tahu di Korea merupakan masakan yang memiliki nilai komposisi gizi yang tinggi. Selain sering menjadi campuran dalam beberapa hidangan termasuk dalam masakan Korea, Tahu memiliki beberapa manfaat. Tahu dari segi ekonomi adalah makanan yang murah, mudah di jumpai, dan sehat. Tahu memiliki kandungan seperti protein. Kualitas protein dalam Tahu hampir sama dengan daging atau susu. Tahu memiliki kandungan lemak jenuh yang cukup rendah dan juga bebas kolesterol. Setiap 100 gram Tahu dapat mengandung sekitar 6-10 gram kandungan protein yang memenuhi 18\% kebutuhan tubuh akan protein (tergantung pada jenis Tahu). Tahu padat lebih kaya akan protein dibandingkan Tahu sutra.

Selain itu, Tahu juga mengandung lemak tak jenuh, karbohidrat, kalori, mineral, fosfor, vitamin B-kompleks, Vitamin E, Vitamin B12, kalium, dan kalsium (yang bermanfaat mendukung terbentuknya kerangka tulang). Selain itu, banyaknya kandungan gizi pada panganan jenis Tahu, membuat Tahu memiliki banyak khasiat bagi kesehatan. Selanjutnya Tahu juga memiliki banyak manfaat, khususnya dari segi kesehatan, seperti mencegah penyakit Jantung, meingkatkan produksi energi, untuk wanita Menopause, mencegah Osteoporosis, menurunkan berat badan, dan membantu penderita diabetes. Sehingga, karena masakan yang berbahan dasar Tahu sangat sehat, murah, praktis dan mudah untuk dibuat. Maka dari itu, masakan berbahan dasar Tahu tidak bisa disepelekan karena Tahu memiliki banyak manfaat bagi kesehatan tubuh kita.

Selain itu, masakan dikemas secara modern dengan keunikan budaya kuliner mereka. Terkait hal tersebut Donnald dan G. Gammack (2007: p.47) menyatakan "Brand awareness and salience are known to positively affect choice among competing products and destinations." Artinya, bahwa informasi tentang merk (brand) dan ciri khas (keunikan) menentukan nilai saing sebuah produk atau destinasi wisata. Merujuk pada pernyataan tersebut sangat tampak bahwa masakan berbahan Tahu di Korea akan menjadi produk wisata kuliner yang memiliki daya saing tinggi dalam dunia wisata kuliner Korea, dengan didukung oleh globalisasi produk-produk wisata Korea yang lain misalnya wisata budaya, musik, dan lain sebagainya.

Beberapa dekade terakhir produk makanan Korea berbahan Tahu sudah merambah ke seluruh dunia, khususnya Indonesia. Produk-produk tersebut bisa ditemukan di berbagai restoran Korea di Indonesia yang tentunya memberikan impuls bagi penikmat wisata kuliner Korea untuk bisa lebih mudah mendapatkannya di Indonesia. Selain itu, keberadaan restoran-restoran Korea yang menyajikan produk-produk makanan tersebut merupakan media stimulasi dalam merangsang minat wisatawan Indonesia untuk datang ke Korea. Dengan demikian, kekuatan pasar (market power) dan nilai daya saing produk-produk tersebut akan mampu memberikan dampak positif perkembangan pariwisata Korea baik di Indonesia maupun di seluruh dunia.

\section{Kesimpulan}

Tahu selain sebagai bahan makanan di Korea juga memiliki nilai filosofis sebagai lambang kesucian dan kebersihan hati. Tahu juga beraneka ragam jenisnya di Korea, yang digunakan sebagai komposisi sajian makanan yang memiliki nilai gizi, 
higienis, dan keunikan tersendiri. Meskipun memiliki kesamaan dalam jenisnya, Tahu Korea mampu menjadi produk wisata kuliner yang diminati oleh para wisatawan manca negara, karena disajikan secara variatif cara penyajiannya dan modern. Selain itu, hal tersebut didukung oleh identitas negara Korea yang secara global memiliki daya tarik tersendiri dalam dunia pariwisata terutama dari wisata kulinernya. Dengan demikian, melalui makanan dari bahan Tahu, secara khas menjadi identitas makanan lokal Korea yang mendunia.

\section{Daftar Pusaka}

Donald, Stephanie Hemelryk dan John G. Gammack. 2007. Tourism and The Branded City. Film and The Identity on The Pasific Rim. Queensland: Griffith University Press.

Geografi Korea. 2017. Retrieved from http://www.visitkorea.or.id/bbs/pa ge.php?hid=geografi_ko

Hyeon-suk, Park. 2013. Korean Cuisine 'Refresh Your Sense'. Seoul: HodgePodge

Kye, Kim. 2009. Modern Korean Kitchen. Seoul: Bookhouse.

Papatheodorou, Andreas. 2006. Corporate Rivalry and Market Power. New York: I. B. Tauris \& Co. Ltd.

Quirky stuff in Korea. 2017. Retrieved from http://www.dramasrok.com/2010/0 3/korea-tofu-prison/
Soyearn, Yoo dan Junghwa, Yoo. 2009. Korean Kitchen. Seoul: Leescom.

Yeong Ho, Ahn. 1995. Kamus Bahasa Indonesia-Korea. Seoul: HUFS.

www.aninditanst.wordpress.com/Tahuputih diunduh pada 25 Mei 2015 pukul 13.59 WIB

www.jawawetan.wordpress.com/Tahukuning diunduh pada 25 Mei 2015 pukul 14.03 WIB

www.diahdidi.com/Tahu-pong diunduh pada 25 Mei 2015 pukul 14.04 WIB www.sebandung.com/Tahu-susu diunduh pada 25 Mei 2015 pukul 14.08 WIB www.fjb.kaskus.co.id/Tahu-sutera diunduh pada 25 Mei 2015 pukul 14.09 WIB www.Tahuyunyi.com/Tahu-air diunduh pada 25 Mei 2015 pukul 14.18 WIB www.agroyasa.com/Tahu-kulit diunduh pada 25 Mei 2015 pukul 14.18 WIB www.blog.daum.net/yeondubu diunduh pada 25 Mei 2015 pukul 14.32 WIB www.blog.daum.net/yubu diunduh pada 25 Mei 2015 pukul 14.42 WIB www.blog.daum.net/ilbandubu diunduh pada 27 Mei 2015 pukul 14.19 WIB www.megamart.com/sundubu diuduh pada 27 Mei 2015 pukul 14.35 WIB www.munhwa.com/biji diunduh pada 27 Mei 2015 pukul 15.38 WIB 